\title{
SOSIALISASI PENCEGAHAN PENYAKIT TBC UNTUK MASYARAKAT FLAMBOYANT BAWAH di KOTA PALANGKA RAYA
}

\author{
Rita Rahmaniati, Nani Apriyani* \\ Dosen Universitas Muhammadiyah Palangkaraya \\ e-mail: rahmaniatirita@yahoo.co.id
}

\begin{abstract}
Abstrak
Pengabdian ini bertujuan: untuk memberikan sosialisasi dan penyuluhan pencegahan penyakit TBC untuk meningkatkan kesadaran masyarakat tentang bahaya penyakit TBC dan pencegahannya.

Metode kegiatan yang digunakan dalam pengabdian ini dalam bentuk pelatihan/worshop dan hasil pelatihan diperesentasikan masing masing kelompok guru, melalui tahapan 1) ceramah 2) simulasi 3) eksplorasi 4) pembimbingan dan 5) evaluasi. Khalayak sasaran atau peserta penyuluhan adalah masyarakat Flamboyant bawah di Kota Palangkaraya.

Hasil dari kegiatan pengabdian menunjukan bahwa masyarakat sangat antusias mengikuti kegiatan penyuluhan terlihat dengan adanya respon yang yang sangat baik. Mengingat kegiatan ini sangat penting untuk menambah pengetahuan masyarakat maka kegiatan ini dapat di lanjutkan di lingkungan masyarakat bawah lainnya agar dapat menjaga kebersihan lingkungan sehingga terhindar dari penyakit menular seperti TBC.
\end{abstract}

\section{Kata Kunci : Penyakit TBC}

\section{Analisis Situasi}

\section{PENDAHULUAN}

Tuberkulosis adalah penyakit menular langsung yang disebabkan oleh kuman TBC (Mycobacterium tuberculosis) (Kemenkes RI, 2013). Tuberkulosis adalah penyakit infeksius, yang terutama menyerang parenkim paru. Sebagian besar kuman TBC menyerang paru, tetapi dapat juga mengenai organ tubuh lainnya termasuk meninges, ginjal, tulang, dan nodus limfe (Smeltzer\&Bare,2002). Tuberkulosis merupakan infeksi bakterikronik yang disebabkan oleh Mycobacterium tuberculosis dan ditandai oleh pembentukan granuloma pada jaringan yang terinfeksi dan oleh hipersensifitas yang diperantarai sel (cell- mediated hypersensitivity) (Kemenkes RI, 2011).

Penyakit tuberculosis disebabkan oleh kuman Mycobacteri umtuberculosis.
Kuman ini berbentuk batang, mempunyai sifat khusus yaitu tahan terhadap asam pada pewarnaan. Oleh karena itu disebut pula sebagai Basil Tahan Asam (BTA) (kemenkes RI,2011). Basil ini tidak berspora sehingga mudah dibasmi dengan pemanasan,sinar matahari dan sinar ultraviolet (Nurarif dan Kusuma, 2013), tetapi dapat bertahan hidup beberapa jam di tempat yang gelap dan lembab. Dalam jaringan tubuh kuman ini dapat dormant, tertidur selama beberapa tahun.

Sumber penularan adalah penderita TBC BTA(+) yang ditularkan dari orang ke orang oleh transmisi melalui udara. Pada waktu berbicara, batuk, bersin, tertawa atau bernyanyi, penderita menyebarkan kuman ke udara dalam bentuk droplet (percikan dahak) besar $(>100 \mu)$ dan kecil $(1-5 \mu)$. Droplet yang besar menetap, sementara 
droplet yang kecil tertahan diudara dan terhirup oleh individu yang rentan (Smeltzer \& Bare, 2002). Droplet yang mengandung kuman dapat bertahan di udara pada suhu kamar selama beberapa jam dan orang dapat terinfeksi kalau droplet tersebut terhirup ke dalam saluran pernapasan.

Setelah kuman TBC masuk ke dalam tubuh manusia melalui pernapasan, kuman TBC tersebut dapat menyebar dari paru ke bagian tubuh lainnya, melalui saluran peredaran darah, system saluran limfe, saluran nafas, atau penyebaran langsung ke bagian-bagian tubuh lainnya. Daya penularan dari seorang penderita ditentukan oleh banyaknya kuman yang dikeluarkan dariparunya. Makin tinggi derajat positif hasil pemeriksaan dahak, makin menular penderita tersebut. Kemungkinan seseorang terinfeksi TBC ditentukan oleh tingkat penularan, lamanya pajanan/kontak dan daya tahan tubuh (Kemenkes RI, 2013).

Penyakit Tuberkulosis tidak hanya menyerang paru saja, seperti pengetahuan masyarakat selama ini. Namun Tuberkulosis ada beberapa macam tingkatan, yaitu:

\section{Tuberkulosis Paru}

Tuberkulosis adalah tuberkulosisyang menyerang jaringan paru(parenkim paru) tidak termasuk pleura (selaput paru).

\section{Tuberkulosis ekstra paru}

Tuberkulosis ekstra paru adalah tuberkulosis yang menyerang organ tubuh lain selain paru, misalnya apleura,selaput otak, selaput jantung (pericardium) kelenjar lymfe, tulang persendian, kulit, usus, ginjal, saluran kencing, alat kelamin dan lain-lain.

TBC ekstra paru dibagi berdasarkan pada tingkat keparahan penyakit yaitu:

\section{TBC Ekstra Paru Ringan}

Misalnya TBC kelenjar limfe, pleuriti seksudativa unilateral tulang (kecuali tulang belakang), sendi, dan kelenjar adrenal.

\section{TBC Ekstra Paru Berat}

Misalnya meningitis, millier, perikarditis, peritionitis, pleuriti seksudativa duplex, TBC tulang belakang, TBC usus, TBC saluran kencing dan alat kelamin.

Gejala utama yang terjadi adalah batuk terus menerus dan berdahak selama tiga minggu atau lebih. Gejala tambahan yang sering terjadi yaitu batuk darah atau dahak bercampur darah, sesak nafas, nyeri dada, badan lemas, keletihan, nafsu makan menurun, berat badan menurun, rasa kurang enak badan (malaise), berkeringat malam walaupun tanpa aktifitas fisik, demam meriang lebih dari sebulan.

Gejala umum TBC anak adalah sebagai berikut:

a. Berat badan turun selama tiga bulan berturut-turut tanpa sebab yang jelas atau berat badan tidak naik tidak naik dalam satu bulan setelah diberikan upaya perbaikan gizi yang baik.

b. Demam yang lama ( $\geq 2$ minggu) dan/atau berulang tanpa sebab yang jelas (bukan demam tifoid, infeksi saluran kemih, malaria, dan lain-lain). Demam umumnya tidak tinggi. Keringat malam saja bukan merupakan gejala spesifik TBC pada anak apabila tidak disertai dengan gejala-gejala sistemik/umum lain.

c. Batuk lama $\geq 3$ minggu, batuk bersifat nonremitting (tidak pernah reda atau intensitas semakin lama semakin parah) dan sebab lain batuk telah dapat disingkirkan.

d. Pembesaran kelenjar limfe superfisialis yang tidak sakit,biasanya multipel, paling sering di daerah leher, ketiak dan lipatan paha.

e. Nafsu makan tidak ada (anoreksia) atau berkurang, disertai gagal tumbuh (failureto thrive).

f. Lesu atau malaise, anak kurang aktif bermain.

g. Diare persisten/menetap (>2minggu) yang 
tidak sembuh dengan pengobatan baku diare.

\section{Permasalahan:}

Masyarakat Flamboyant bawah merupakan msyarakat yang tinggal di tepian sungai kahayan, memiliki rumah berbentuk panggung di lokasi yang tergenang air (rawa). Kultur masyarakat di Flamboyant bawah dalam membangun rumah dengan jarak yang cukup rapat anatara rumah yang satu dengan rumah yang lainnya. Berdasarkan observasi ke lingkungan Flamboyant bawah menunjukkan bahwa sebagian besar masyarakat kurang menjaga lingkungannya dengan baik. Baik itu didalam rumah maupun di luar rumah.Hal ini terlihat dari ventilisasi udara didalam rumah yang kurang baik, rumah kecil dihuni oleh anggoata keluarga yang cukup banyak jumlahnya, kebiasaan meludahsembarangan, sanitasi air yang kurang baik dan kurang menjaga kebersihan lingkungan sekitar.

Fakta lain menunjukkan bahwa beberapa masyarakat yang terindikasi penyakt tertentu seperti penyakit menular (TBC) kurang kesdarannya untuk berobat di tenaga kesehatan atau di tempat layanan kesehatan lainnya, sehingga mengakibatkan potensi penularan yang lebih tinggi dan kematian.

Melihat kondisi itu, dipandang perlu diadakan penyuluhan tentang pencegahan penyakit TBC bagi masyarakat Flamboyant bawah agar penyakit TBC dapat dicegah sebelum terjangkit dan berobat dengan rutin dan teratur jika sudah terindikasi mengidap penyakit TBC.

\section{Tujuan}

Adapun tujuan kegiatan pengabdian ini adalah :

1. Membantu program pemerintah dalam meningkatkan kesehatan masyarakat.

2. Sosialisasi dan penyuluhan pencegahan penyakit TBC.untuk meningkatkan kesadaran masyarakat tentang bahaya penyakit TBC dan pencegahannya.

3. Silaturahmi dosen UM Palangkaraya ke lingkungan Flamboyant bawah.

\section{METODE PELAKSANAAN}

Pelaksanaan Pengabdian masyarakat ini dilaksanakan selama 1 bulan sejak 23-24 oktober 2017, bertempat di Komplek Flamboyant Bawah Kota Palangkaraya. Khalayak sasaran atau peserta sosialisasi adalah ibu-ibu, bapak-bapak serta masyarakat lainnya di Flamboyant bawah yang berjumlah sekitar 30 orang.Kegiatan ini dilaksanakan dalam bentuk sosialisasi disertai tanya jawab di tengah-tengah penjelasan maupun di akhir materi sosialisasi.

Aktivitas kegiatan pengabdian sosialisasi pencegahan penyakit TBC dapat disajikan pada tabel berikut :

\begin{tabular}{|c|c|c|c|c|}
\hline No & $\begin{array}{l}\text { Hari/ta } \\
\text { nggal }\end{array}$ & Kegiatan & $\begin{array}{l}\text { Met } \\
\text { ode }\end{array}$ & $\begin{array}{l}\text { Ketera } \\
\text { ngan }\end{array}$ \\
\hline \multirow[b]{2}{*}{1.} & \multirow[b]{2}{*}{$\begin{array}{l}\text { Senin, } \\
23 \\
\text { Oktobe } \\
\text { r } 2017\end{array}$} & $\begin{array}{l}\text { Mengurus } \\
\text { surat ijin } \\
\text { penelitian } \\
\text { dan surat } \\
\text { tugas oleh } \\
\text { LP2M } \\
\text { UM } \\
\text { Palangkar } \\
\text { aya }\end{array}$ & - & $\begin{array}{l}\text { Surat } \\
\text { selesai } \\
\text { di buat } \\
\text { oleh } \\
\text { pihak } \\
\text { LP2M } \\
\text { dalam } \\
\text { waktu 1 } \\
\text { hari (1 } \\
\text { jam) }\end{array}$ \\
\hline & & $\begin{array}{l}\text { Bersilatura } \\
\text { hmi } \\
\text { kerumah } \\
\text { Ketua } \\
\text { RT/RW di } \\
\text { Flamboya } \\
\text { n Bawah } \\
\text { mengantar } \\
\text { kan surat } \\
\text { ijin } \\
\text { penelitian } \\
\text { serta surat } \\
\text { tugas. }\end{array}$ & - & $\begin{array}{l}\text { Kegiata } \\
\mathrm{n} \\
\text { sosialis } \\
\text { asi } \\
\text { yang } \\
\text { telah } \\
\text { direnca } \\
\text { nakan } \\
\text { diterim } \\
\text { a / } \\
\text { disamb } \\
\text { ut baik, } \\
\text { dan } \\
\text { TIM }\end{array}$ \\
\hline
\end{tabular}




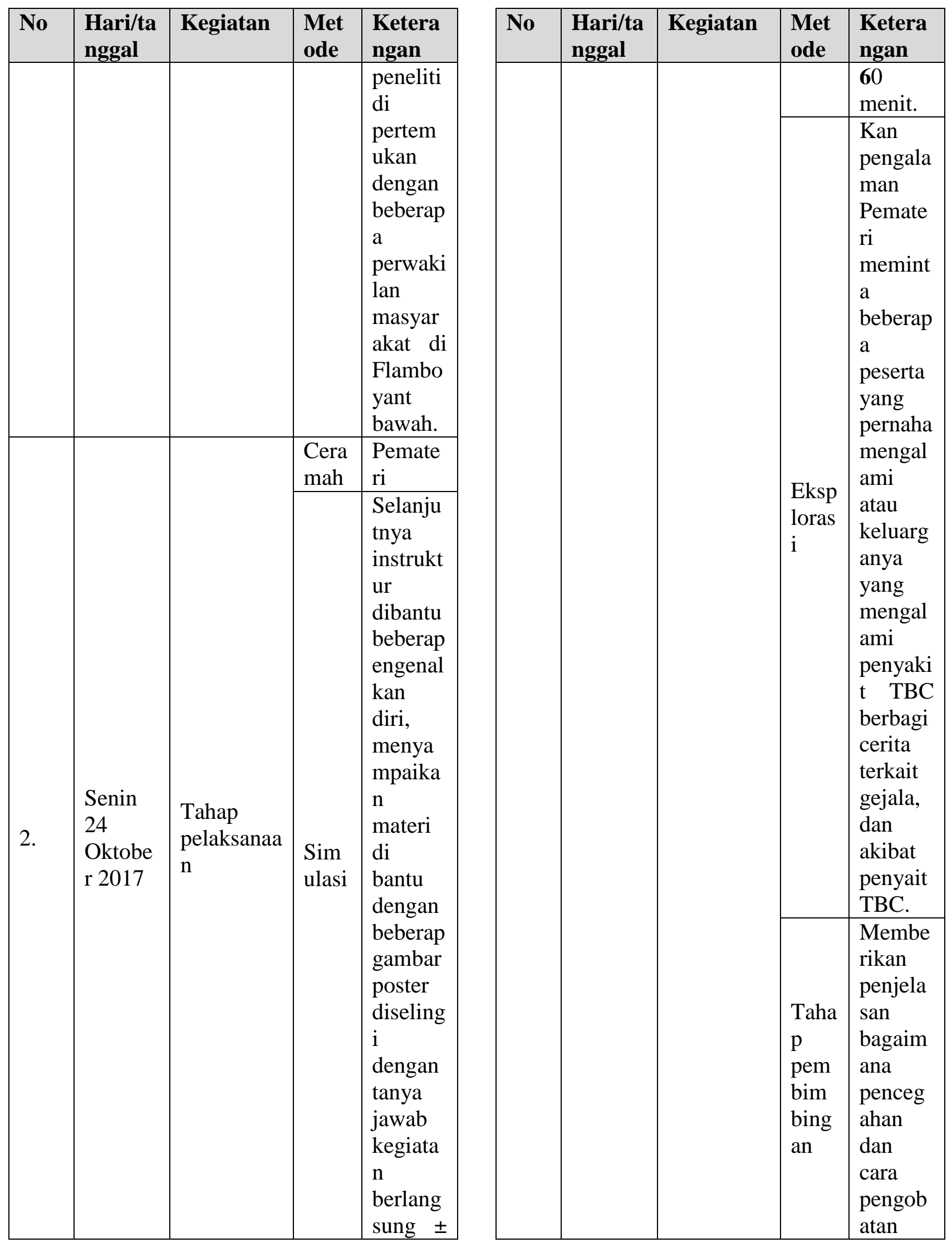




\begin{tabular}{|c|c|c|c|c|}
\hline No & $\begin{array}{l}\text { Hari/ta } \\
\text { nggal }\end{array}$ & Kegiatan & $\begin{array}{l}\text { Met } \\
\text { ode }\end{array}$ & $\begin{array}{l}\text { Ketera } \\
\text { ngan }\end{array}$ \\
\hline & & & $\begin{array}{l}\text { Eval } \\
\text { uasi }\end{array}$ & $\begin{array}{l}\text { penyaki } \\
\mathrm{t} \text { TBC, } \\
\text { dengan } \\
\text { pola } \\
\text { hidup } \\
\text { sehat, } \\
\text { mulai } \\
\text { dari } \\
\text { MCK, } \\
\text { sanitasi } \\
\text { Air, } \\
\text { dan } \\
\text { makan } \\
\text { makana } \\
\mathrm{n} \text { yang } \\
\text { bergizi } \\
\text { dan } \\
\text { melalui } \\
\text { pengob } \\
\text { atan } \\
\text { yang } \\
\text { rutin, } \\
\text { jika } \\
\text { positif } \\
\text { mengid } \\
\text { ap } \\
\text { TBC. } \\
\text { Membe } \\
\text { rikan } \\
\text { kesemp } \\
\text { atan } \\
\text { masyar } \\
\text { akat } \\
\text { sasaran } \\
\text { untuk } \\
\text { bertany } \\
\text { a jawab } \\
\text { terkait } \\
\text { dengan } \\
\text { kegiata } \\
\mathrm{n} \text { yang } \\
\text { telah } \\
\text { dilakuk } \\
\text { an. }\end{array}$ \\
\hline
\end{tabular}

\begin{tabular}{|c|c|c|c|c|}
\hline No & $\begin{array}{l}\text { Hari/ta } \\
\text { nggal }\end{array}$ & Kegiatan & $\begin{array}{l}\text { Met } \\
\text { ode }\end{array}$ & $\begin{array}{l}\text { Ketera } \\
\text { ngan }\end{array}$ \\
\hline & & & $\begin{array}{l}\text { Refl } \\
\text { eksi }\end{array}$ & $\begin{array}{l}\text { Tim } \\
\text { pengab } \\
\text { dian } \\
\text { melaku } \\
\text { kan } \\
\text { refleksi } \\
\text { hasil } \\
\text { kegiata } \\
\text { n } \\
\text { sosialis } \\
\text { asi. }\end{array}$ \\
\hline 6. & $\begin{array}{l}29,30 \\
\text { oktober } \\
2017\end{array}$ & $\begin{array}{l}\text { Tahap } \\
\text { pelaporan }\end{array}$ & $\begin{array}{l}\text { Men } \\
\text { yusu } \\
\mathrm{n} \\
\text { lapo } \\
\text { ran }\end{array}$ & $\begin{array}{l}\text { Mengu } \\
\text { mpulka } \\
\mathrm{n} \\
\text { semua } \\
\text { berkas } \\
\text { dan } \\
\text { dokume } \\
\text { ntasi } \\
\text { kegiata } \\
\text { n } \\
\text { pengab } \\
\text { dian }\end{array}$ \\
\hline 7. & $\begin{array}{l}1-9 \\
\text { Novem } \\
\text { ber } \\
2017\end{array}$ & & & $\begin{array}{l}\text { Lapora } \\
\mathrm{n} \\
\text { terkum } \\
\text { pul } \\
\text { tepat } \\
\text { waktu. }\end{array}$ \\
\hline
\end{tabular}

\section{HASIL DAN PEMBAHASAN}

Hasil yang ingin dicapai dalam kegiatan pengabdian ini adalah masyarakat Flamboyant bawah mulai mengerti dan wawasannya bertambah, hal ini terlihat dari kesediaan ibu-ibu dan bapk-bapak menjadi peserta aktif dari awal hingga akhir acara.

Respon peserta yang sangat antusias mengikuti acara dari pukul 13.30- 16.00 menunjukkan bahwa masyarakat serius dan semangat mengikuti kegiatan pelatihan. Hasil angket yang telah dibagikan setelah sosialisasi menunjukkan bahwa selama 
mengikuti kegiatan masyarakat merasa senang $100 \%$, merasa senang terhadap isi materi pelatihan $100 \%$, merasa senang dengan pemateri $100 \%$, merasa senang terhadap suasana sosialisasi $100 \%$, dan $100 \%$ merasa senang terhadap cara penyajian materi oleh pemateri. Masyarakat menganggap bentuk kegiatan seperti ini baru bagi meraka $100 \%$. Selanjutnya hanya $50 \%$ masyarakat yang menyatakan mudah tentang sosialisasi ini, 50\% lainnya menyatakan cukup mudah. Selama kegiatan berlangsung, masyarakat dapat menyatakan pertanyaan $100 \%$, dan masyarakat $100 \%$ merasa sosialisasi ini bermanfaat bagi mereka.

Saat penyampaian materi peserta diberikan poster (gambar) terkait dengan penyakit TNC dan pencegahannya, sehingga masyarakat lebih antusias bertanya bahkan ada yang tidak dapat kesempatan karena banyaknya yang peminat bertanya namun waktu tidak memungkinkan untuk di teruskan. Penggunaan poster sangat efektif sebagai media yang mampu menterjemahkan bahasa pemateri yang mungkin tidak semua peserta dapat memahami nya dengan baik. Hal ini senaa dengan pendapat Menurut Hamalik (2006:26) "pemanfaatan media poster sebagai media pembelajaran merupakan salah satu upaya dalam rangka menarik minat belajar peserta didik. Oleh sebab itu, fungsi utama dari media poster dalam pembelajaran adalah sebagai alat bantu mengajar yang di gunakan guru". Sedangkan Menurut Sadiman dkk (2007:9), manfaat poster antara lain : 1) Menimbulkan daya tarik bagi pembelajar. Gambar dengan berbagai warna akan lebih menarik dan membangkitkan minat serta perhatian pembelajar 2) Mempermudah pengertian pembelajar. Suatu penjelasan yang sifatnya abstrak dapat dibantu dengan poster sehingga pembelajar lebih memahami apa yang dimaksud 3) Memperjelas bagianbagian yang penting. Melalui poster dapat diperbesar bagian-bagian yang penting atau yang kecil sehingga dapat diamati lebih jelas 4) Menyingkat suatu uraian panjang. Uraian tersebut dapat ditunjukan dengan sebuah poster saja.

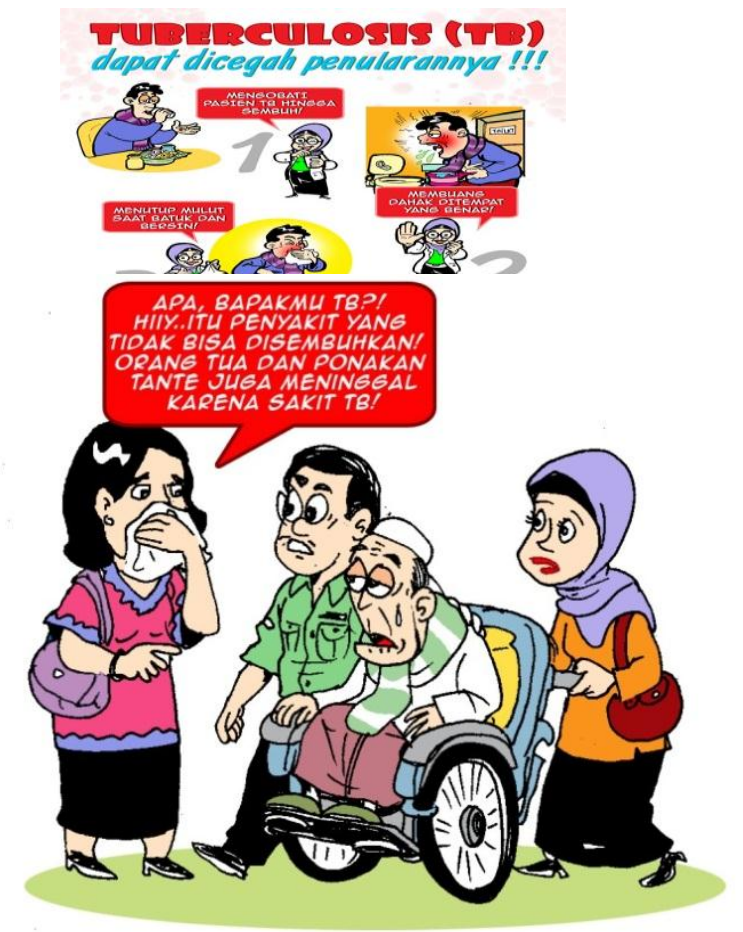

Pelatihan ini sangat bernilai/ bermanfaat bagi masyarakat Flamboyant bawah yang telah mengikuti sosialisasi, karena selama ini sebagian masyarakat belum bisa menerapkan pola hidup dan menciptakan lingkungan yang bersih karena belum banyak memiliki wawasan terhadap penyakit menular, baik penyebaran maupun pencegahannya. Sebagian lainnya masih belum terbiasa berobat ke layanan kesehatan seperti puskesmas atau rumah sakit karena terkendala biaya dll.

Kegiatan terakhir yang dilakukan adalah pemberian doorprize yang diberikan kepada peserta yang dapat menjawab pertanyaan-pertanyaan yang diajukan oleh pemateri. Pemberian Doorprize ini untuk menambah semangat para peserta dan sebagai bentuk penghargaan dan apresiasi kepada masyarakat Flamboyant bawah yang 
sudah berkenan meluangkan waktunya dan berperan aktif untuk kegiatan sosialisasi.

Gambar 1 Sosialisasi Pencegahan Penyakit TBC Untuk Masyarakat Flamboyant Bawah di Kota Palangka Raya

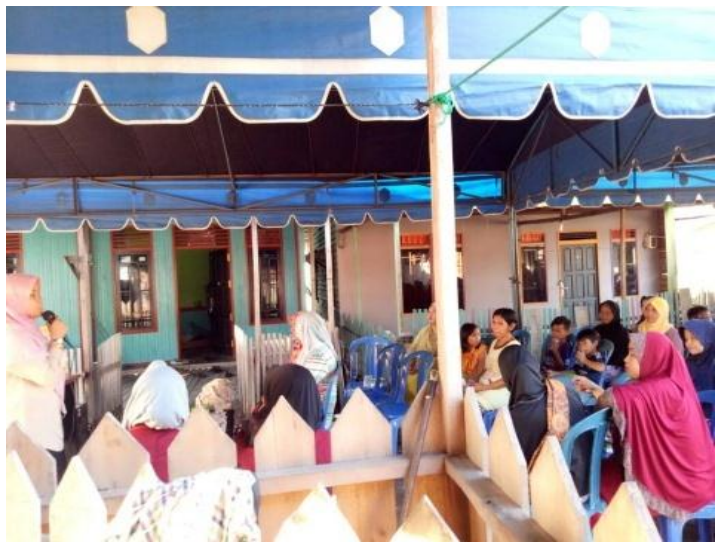

Sambutan Panitia Pelaksana

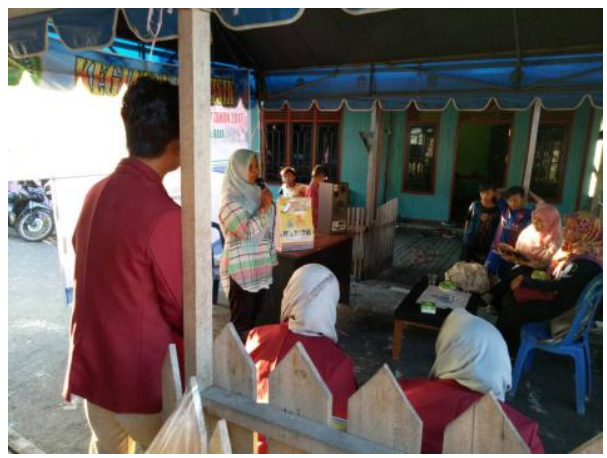

Penjelasan materi dengan media poster

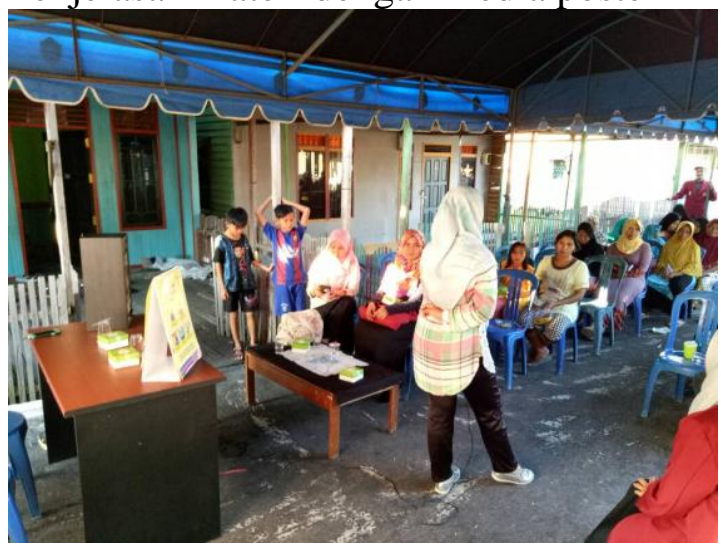

Memberikan kesempatan siswa untuk bertanya

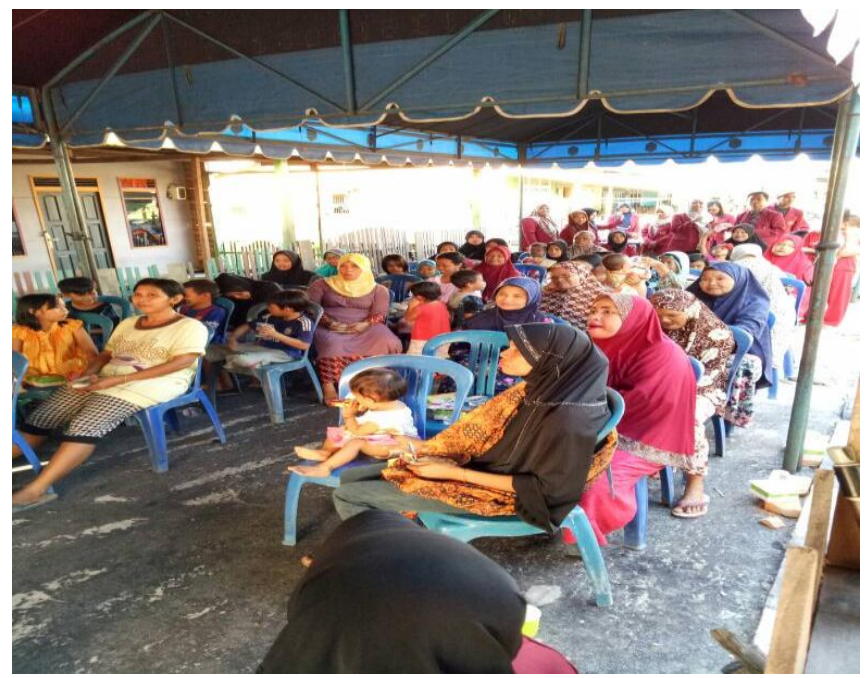

Memberikan kesempatan masyarakat untuk bertanya yang lainnya mendengarkan.

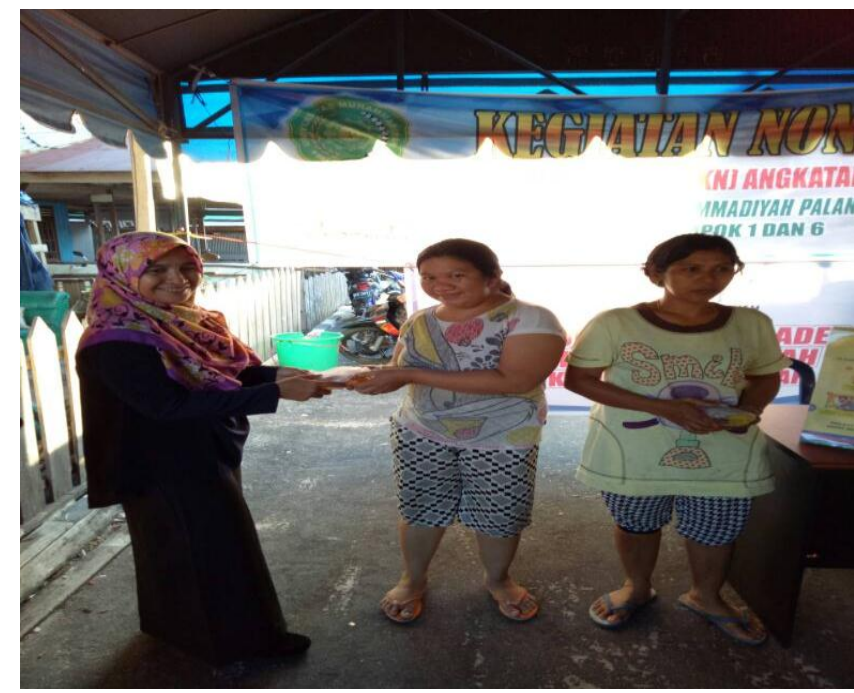

Pemberian Doorprize 


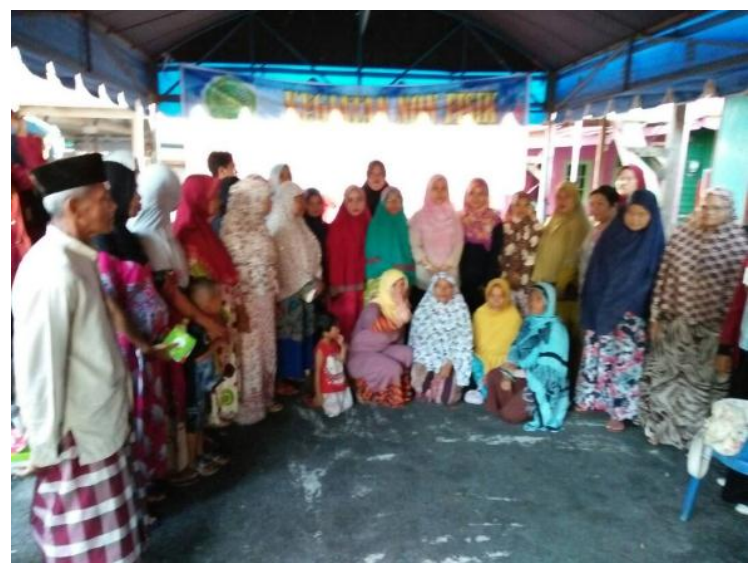

Foto bersama di akhir kegiatan

\section{SIMPULAN DAN SARAN}

Kegiatan pengabdian ini dalam bentuk sosialisasi mampu menambah wawasan masyarakat. Kegiatan pengabdian dapat dikatakan sukses berjalan sesuai rencana, karena peserta memberikan respon positif dan sangat antusias mengikuti kegiatan sosialisasi, namun ada beberapa saran sebagai berikut:

1. Kegiatan pengabdian ini masih memungkin untuk dilanjutkan pada kegiatan yang lebih luas baik dari segi materi maupun masyarakat sasaran.

2. Perlunya penambahan waktu dan dana kegiatan sosialisasi.

\section{DAFTAR PUSTAKA}

Hamalik, Oemar. (2006). Proses BelajarMengajar Berdasarkan Pendekatan Sistem. Jakarta: Bumi Aksara.

Kemenkes RI (2011). Pedoman Nasional Pengendalian Tuberkulosis. Jakarta : Kemenkes.

Mulyono. 2012. Strategi Pembelajaran. Malang: UIN-Maliki Press.

Riset Kesehatan Dasar (Riskesdas).(2013). Badan Penelitian dan Pengembangan Kesehatan Kementerian RI tahun 2013. 